\title{
Merger Control and Online Platforms: The Relevance of Network Effects*
}

\author{
Antonio Robles Martín-Laborda ${ }^{\star *}$
}

\begin{abstract}
Digital platforms operate in multisided markets providing services through the internet to two or more distinct groups of users, between which there are indirect network effects. Direct network effects are frequently present within each group. Therefore, online platforms usually present both direct network effects, between individual members of the same group, and indirect network effects, between members of distinct groups. Network effects may simultaneously reduce competition leading to a greater concentration and strengthening entry barriers, on the one hand, and put forward significant efficiencies on the other. This article examines some key aspects related to the impact of network effects on the assessment of mergers in two-sided markets, taking account of the recent practice of the Commission.
\end{abstract}

KEYWORDS: Online platforms, multi-sided markets, network effects, merger control, efficiency

\section{Introduction}

Digital platforms operate in multisided markets providing services through the internet to two or more distinct groups of users, between which there are indirect network effects. ${ }^{1}$ Direct network effects are also frequently present within each group. Direct network effects arise if the users of one service (i.e., one side of the platform) directly benefit when more people use

\footnotetext{
* Date of reception: 19 July 2017. Date of acceptance: 01 August 2017

** Assistant Professor of Commercial law, School of Law and Social Sciences, Department of Private Law, Universidad Carlos III de Madrid, 28903 Getaf, Madrid, Spain. antonio.robles@uc3m.es. (ORCID: 0000-0003-1179- 0426). This research has been funded by the Spanish Plan Nacional de I+D del Ministerio de Economía y Competitividad (DER2016-78572-P).

${ }^{1}$ See Bundeskartellamt, "Working Paper - Market Power of Platforms and Networks" (2016): 13.
} 
the same service as well (e.g., communication or social network services). Indirect network effects exist when the value of a service for a specific group of users increases with the number of users of another group (i.e., platforms with more users of each group are more valuable to the other groups). Therefore, online platforms usually present both direct network effects, between individual members of the same group, and indirect network effects, between members of distinct groups. ${ }^{2}$

Network effects may reduce competition leading to a greater concentration and strengthening entry barriers on the one hand and, on the other, put forward significant efficiencies. Digital platforms have minimised search and transaction costs and contributed to the dynamic development of an increasing number of markets, thus improving consumer welfare. They have already brought undeniable efficiency gains, increased consumer choice, improved competitiveness and enhanced consumer welfare in activities like advertising, search engines, communications services, payment systems and platforms for the collaborative economy. Simultaneously, network effects might constitute a barrier to entry or expansion and lead to a higher level of concentration in the relevant market. In the case of online platforms, this trend is reinforced by the use of information and communications technologies to collect and process large amounts of data, as by their capacity to reach their users almost instantly. Both direct and especially indirect network effects tend to lead to concentrated markets. Consequently, digital platforms have attracted the interest of the competition authorities. ${ }^{3}$

As the recent practice of the Commission has stressed, the special competitive dynamics of online platforms - underlined by the huge difference between the purchase price and the revenues generated by the acquired firms ${ }^{4}-$ represent a challenge from a competition policy perspective and, in particular, in order to assess the foreseeable impact of a merger on the relevant market.

\footnotetext{
${ }^{2}$ See Michael Katz and Carl Shapiro, "Network Externalities, Competition, and Compatibility", American Economic Review 75 (1985): 424-440; Michael Katz and Carl Shapiro, "Systems of Competition and Network Effects", The Journal of Economic Perspectives 8 (1994): 93-115.

${ }^{3}$ See the Commission communication of 25 May 2016 on "Online Platforms and the Digital Single Market - Opportunities and Challenges for Europe" (COM(2016)288) and the accompanying Commission staff working document (SWD(2016)0172); House of Lords. Select Committee on European Union, "Online Platforms and the Digital Single Market", April 2016; Bundeskartellamt, "Power of Platforms and Networks" (2016).

${ }^{4}$ See Daniel Zimmer, "Digital Markets: New Rules for Competition Law", Journal of European Competition Law and Practice 6 (2015): 627-628; Monopolkommission, "Competition policy: The challenge of digital markets", Special Report No 68 (2015): 105-108, accessed July 2, 2017: http:// www.monopolkommission.de/images/PDF/SG/s68_fulltext_eng.pdf.
} 
Pursuant Council Regulation (EC) No 139/2004 of 20 January 2004 on the control of concentrations between undertakings, the Commission must assess whether a concentration would significantly impede effective competition, in particular as a result of the creation or strengthening of a dominant position, in the common market or a substantial part of it. Therefore, according to the consumer welfare standard, ${ }^{5}$ the Commission prevents mergers likely to deprive customers of the benefits brought by competition by significantly increasing the market power of the merging firms, which is defined as "the ability of one or more firms to profitably increase prices, reduce output, choice or quality of goods and services, diminish innovation, or otherwise influence parameters of competition". ${ }^{6}$

The potential effects of a given concentration depend on its horizontal or non-horizontal nature. Within these categories, they can be characterised as either coordinated or unilateral (non-coordinated). Unilateral horizontal effects are the most likely to result in consumer harm. Horizontal mergers may significantly impede effective competition in a market by removing some existing competitive constraint on one or more sellers, which consequently would have increased market power. The loss of competition between the merging firms is the most direct effect of the merger since the reduction of this competitive constraint could lead to significant price increases. Conversely, non-horizontal (i.e., vertical or conglomerate) mergers do not entail the loss of direct competition between the merging firms in the same relevant market, and may provide substantial scope for efficiencies by integrating complementary activities or products and reducing transaction costs. However, there are circumstances in which non-horizontal mergers may significantly impede effective competition through non-coordinated effects, principally when it gives rise to foreclosure, hampering actual or potential rivals' access to supplies or markets. The analysis of a concentration under the heading of coordinated effects deals with the risk that it increases the likelihood that firms are able to coordinate their competitive behavior, even without entering into an agreement or resorting to a concerted practice. ${ }^{7}$

\footnotetext{
${ }^{5}$ Svend Albaek, "Consumer Welfare in EU Competition Policy" in Aims and Values in Competition Law, ed. Caroline Heide-Jørgensen, Christian Bergqvist, Ulla Neergaard and Sune Troels Poulsen (DJØf Publishing, 2013), 67-88.

${ }^{6}$ Horizontal Guidelines, paragraph 8.

${ }^{7}$ Horizontal Merger Guidelines, paragraph 39.
} 
Market shares and overall concentration level in the relevant market are usually the starting point for the substantive assessment of both horizontal and non-horizontal mergers, as they provide useful first indications of the market structure and of the competitive importance of both the merging parties and their competitors. ${ }^{8}$ The calculation of market shares and, hence, the assessment of the marker power, depend critically on market definition. Although market shares only provide first indications for the assessment, the larger the market share, the more likely the merged entity is to possess market power. Absent exceptional circumstances, very large market shares are in themselves evidence of a dominant position. ${ }^{9}$ However, the importance of market shares may vary in the light of likely market conditions of the particular relevant market. Since digital markets are highly dynamic and their market structure is usually unstable due to innovation and growth, the Commission has established that a high market share only provides a limited indication of competitive strength, but it is not a reliable indicator of market power in the case of online platforms. ${ }^{10}$ This view has been confirmed by the General Court. ${ }^{11}$ For this reason the market dominance should be assessed giving a particular weight to the specifics of platform and network markets, notably the relevance of direct and indirect network effects, the economies of scale, the prevailing types of use on the opposite market side (single-homing/ multi-homing) and the degree of differentiation, the access to data and the innovation potential of digital markets. ${ }^{12}$ In particular, to determine the impact of a merger that involves a two-sided platform on market power, one has to take into account the interrelated effects on both customer groups served by the platform. The interdependency between their distinct sides means that the adjustment of the price charged to one group of users affects the demand level of the other groups; i.e., the platform may influence the production level not only changing the price level, but also its structure. This link between the users

\footnotetext{
${ }^{8}$ Horizontal Merger Guidelines, paragraph 14; Guidelines on the assessment of non-horizontal mergers under the Council Regulation on the control of concentrations between undertakings, [2008] OJ C 265/6, paragraph 24.

${ }^{9}$ Judgment of 13 February 1979, Hoffmann-La Roche \& Co. AG v Commission of the European Communities, C-85/76, EU:C:1979:36, paragraph 41.

${ }^{10}$ See Microsoft/Skype, paragraphs 78, 98; Facebook/Whatsapp, paragraph 99.

${ }^{11}$ Judgment of 11 December 2013, Cisco Systems Inc., T-79/12, EU:T:2013:635, paragraph 69.

${ }^{12}$ See Bundeskartellamt, "Market Power of Platforms and Networks", 43-85. In the case of networks, the same assessment criteria should be taken into account along with direct network effects. See Bundeskartellamt, "Market Power of Platforms and Networks", 86-102.
} 
of distinct sides affects the price elasticity of demand and, consequently, the profitability of a price increase on either side of the platform. An increase in the price (or a reduction of quality) to one side reduces the value that the costumers of other sides receive from the platform, which, therefore, reduces in turn the demand and price they are willing to pay. ${ }^{13}$ This implies that some of the traditional tools for merger analysis do not apply unless appropriately reformulated to account for the two-sidedness of the market. ${ }^{14}$

The aim of this article is to discuss some aspects related to the influence of both direct and indirect network effects on the assessment of mergers involving online platforms ${ }^{15}$ and to assess the adequacy of the recent practice of the Commission. ${ }^{16}$ For that purpose, it analyses the definition of the relevant market as the first step to the assessment of any notified merger, given its multi-sided nature (section 2), the account of network effects as a

${ }^{13}$ See Jean-Charles Rochet and Jean Tirole, "Platform Competition in Two-Sided Markets", Journal of the European Economic Association 1 (2003): 990-1029; Bernard Caillaud, and Bruno Jullien, "Chicken and Egg: Competition among Intermediation Service Providers", RAND Journal of Economics 34 (2003): 309-328; D. S. Evans, "The Antitrust Economics of Multi-Sided Platform Markets”, Yale Journal on Regulation 20 (2003): 325-381; David S. Evans and Richard Schmalensee, "The Industrial Organization of Markets with Two-Sided Platforms", Competition Policy International 3 (2007): 151-179.

${ }^{14}$ See Julian Wright, "One-Sided Logic in Two-Sided Markets", Revue of Network Economics 3 (2004): 44-64. But see also Dirk Auer and Nicolas Petit, "Two-Sided Markets and the Challenge of Turning Economic Theory into Antitrust Policy", The Antitrust Bulletin 60 (2015): 426-461.

${ }^{15}$ Other relevant factors, and, in particular, the impact of big data on market power, are not directly analysed. See Andres V. Lerner, "The Role of 'Big Data' in Online Platform Competition" (2014) SSRN Electronic Journal, accessed 29 July 2017: http://papers.ssrn.com/sol3/papers.cfm?abstract_ id=2482780; Francisco Costa-Cabral and Orla Lynskey, "The Internal and External Constraints of Data Protection on Competition Law in the EU", LSE Law, Society and Economy Working Papers 25/2015, SSRN Electronic Journal, accessed 3 August 2017, http://eprints.lse.ac.uk/64887/1/ Lynskey_Internal\%20and\%20External\%20Constraints\%20of\%20Data\%20Protection\%20_ Author_2015.pdf; Inge Graef, EU Competition Law, Data Protection and Online Platforms: Data as Essential Facility, Kluwer Law International (2016); Inge Graef, "Market Definition and Market Power in Data: The Case of Online Platforms", World Competition Law and Economics Review, 38 (2015): 473-506; Joint Paper of the Autorite de la concurrence and the Bundeskartellamt on Competition Law and Data (2016): 11, accessed July 2, 2017, http://www.bundeskartellamt.de/ SharedDocs/Publikation/DE/Berichte/Big\%20Data\%20Papier.pdf?__blob=publicationFile\&v=2; Annabelle Gawer, "Competition Policy and Regulatory Reforms for Big Data: Propositions to Harness the Power of Big Data while Curbing Platforms' Abuse of Dominance", in OECD, Big Data: Bringing Competition Policy to the Digital Era", DAF/COMP/WD(2016)74.

${ }^{16}$ See Commission Decisions of 21 Aug 2007M.4523 - Travelport/Worldspan; 11 March 2008, M. 4731 - Google / DoubleClick; 7 October 2011, M.6281 - Microsft/Skype, 3 Oct. 2014, M.7217 Facebook/Whatsapp; 6 December 2016, M.8124 - LinkedIn. 
barrier to entry or expansion (section 3), the relevance of indirect network effects to assess the platforms' power over price (section 4) and the role of efficiencies put forward as a plausible countervailing factor (section 5), trying to draw some conclusions on the status quaestionis and the policy underlying the doctrine of the Commission (section 6).

\section{The definition of the relevant market in a multi-sided context}

The assessment of whether or not a concentration would create or strengthen a dominant position depends critically on the proper identification of the competitive constraints faced by the merging entities, preventing them from behaving independently of effective competitive pressure. Therefore, the main purpose of market definition is to identify the competitors of the undertakings involved that are capable of constraining their ability to profitably increase prices (or reduce innovation, output, choice, or quality of goods and services). ${ }^{17}$ The relevant market is established by the combination of the product and geographic markets. According to the Commission, the relevant product market "comprises all those products and/or services which are regarded as interchangeable or substitutable by the consumer, by reason of the products' characteristics, their prices and their intended use". ${ }^{18}$ Since a firm cannot significantly impact the prevailing prices if its customers are in a position to switch easily to available substitute products, demand substitution constitutes the most immediate and effective competitive constraint on the suppliers of a given product.

However, the proper identification of the relevant product market presents a greater complexity in multi-sided markets than in the case of one-sided markets. In multi-sided markets, the link between the users of distinct sides affects the price elasticity of demand and, consequently, the profitability of a price increase on either side of the platform. An increase in the price (or a reduction of quality) to one side reduces the value that the costumers of other sides receive from the platform, which, therefore, reduces in turn the demand and the price they are willing to pay. Moreover, online platforms frequently offer services and contents free of charge (e.g. search engines, social network services) to users on one side of the market in order to benefit of indirect network effects on the other. Therefore, the

\footnotetext{
${ }^{17}$ See Commission Notice on the definition of relevant market for the purposes of Community competition law, [1997] OJ C 372/5. But see Louis Kaplow, "Why (Ever) Define Markets?", Harvard Law Review 124 (2010): 437-517.

${ }^{18}$ Notice on the definition of relevant market, paragraph 2.
} 
two interrelated aspects of how many relevant markets must be defined and the incidence of gratuity in one side of the platform must be ascertained. ${ }^{19}$ Since the nature of the product offered to each side of the platform leads to different types of indirect network effects, ${ }^{20}$ a systematic distinction can be made between transaction and non-transaction markets. ${ }^{21}$

Non-transaction (advertising) platforms enable one group of users to get the attention of another users' group. This audience providing platforms frequently offer free services and contents (e.g. search engines, social network services) to users on one side, which constitute the target of the advertising space offered for a price to the advertisers on the other side. Only one group (the advertisers) benefits from the growing number of users on the other side of the platform, thus producing unilateral indirect network effects. Since the service offered to one side is different than the service offered to the other, each of them could be considered as a relevant product market..$^{22}$ However, the fact that some of them are offered free of charge must be taken into account. In this sense, the Commission did not initially define a market on the free side of the platform. In Google/ DoubleClick it defined different relevant product markets in the paid side of the platform (provision of online advertising space, intermediation in online advertising and provision of online display ad serving), ${ }^{23}$ excluding the services offered free of charge to the other (search engine). However, the Commission and the General Court have subsequently accepted that the use of online platforms free of charge can also constitute a relevant market under competition law. ${ }^{24}$

The existence of a market where a service is offered free of charge remains controversial. In practice, the Commission applies the so-called SSNIP

\footnotetext{
${ }^{19}$ See Bundeskartellamt, “The Market Power of Platforms and Networks", 25-39.

${ }^{20}$ It may also lead to different geographic markets on each side. See Travelport/Worldspan, paragraphs 60-71.

${ }^{21}$ See Lapo Filistrucchi, Damien Geradin, Eric van Damme and Pauline Affeldt, "Market Definition in Two-Sided Markets: Theory and Practice", Journal of Competition Law and Economics 10 (2014): 293-339; Florence Thépot, "Market Power in Online Search and Social Networking: A Matter of Two-Sided Markets", World Competition, 36 (2013): 95-221; Bundeskartellamt, “The Market Power of Platforms and Networks", 18-26.

${ }^{22}$ See Lapo Filistrucchi, Damien Geradin, Eric van Damme and Pauline Affeldt, "Market Definition in Two-Sided Markets: Theory and Practice", 318; Bundeskartellamt, "Market Power of Platforms", 29-30.

${ }^{23}$ Google/DoubleClick, paragraphs 44-91.

${ }^{24}$ Microsft/Skype; Facebook/Whatsapp; Judgment of 11 December 2013, Cisco Systems Inc., T-79/12, EU:T:2013:635.
} 
test. According to it, the question to be answered is whether the parties' customers would switch to readily available substitutes or to suppliers located elsewhere in response to a hypothetical small but significant non-transitory increase in the price of the products and areas being considered. When substitution is deemed enough to make the price increase unprofitable because of the resulting loss of sales, additional substitutes and areas are included in the relevant market, until the set of products and geographical areas is such that small, permanent increases in relative prices would be profitable. ${ }^{25}$ The suitability of the traditional SSNIP test to services offered free of charge is limited, ${ }^{26}$ which reveals the need to modify the test or to adopt a different one for defining markets in the case of multi-sided platforms. ${ }^{27}$ The existence of free markets raises also important conceptual concerns. ${ }^{28}$ The assessment of demand substitution entails a determination of the range of products which are considered as substitutes from the point of view of the users of each side of the platform, although, from the platform (i.e., the supplier) point of view, the different services offered to each side are considered as a unit. In fact, there is a competitive relationship between the different services offered free of charge, whether social networks or search engines. An increase in the demand for one of them could lead to a reduction in the demand for the others, since all of them compete for advertisers in the paid side of the platform (i.e., the market of online advertising). ${ }^{29}$ The apparently free use of the platform is subsidised by the other group of users and, in turn, the profitability of the paid service depends on the outreach

\footnotetext{
${ }^{25}$ Notice on the definition of relevant market, paragraphs 15-19.

${ }^{26}$ See David S. Evans and Vanessa Yanhua Zhang, "Qihoo 360 v Tencent: First Antitrust Decision by The Supreme Court", CPI blog, accessed July 2, 2017, https://www.competitionpolicyinternational.com/qihoo-360-v-tencent-first-antitrust-decision-by-the-supreme-court.

${ }^{27}$ See Lapo Filistrucchi, "A SSNIP Test for Two-Sided Markets: The Case of Media", NET Institute Working Paper 08-34, October 2008, accessed July 2, 2017, https://papers.ssrn.com/ sol3/papers.cfm?abstract_id=1287442; OECD, "Policy Roundtables: Two-Sided Markets", DAF/ COMP(2009)20, 35-36; David S. Evans and Richard Schmalensee, "Market Definition and Merger Analysis for Multi-Sided Platforms", Competition Policy International (2012), accessed July 2, 2017, https://www.competitionpolicyinternational.com/assets/Uploads/MSP11-13-3.pdf; Lapo Filistrucchi, Damien Geradin, Erin van Damme and Pauline Affeldt, "Market Definition in Twosided Markets: Theory and Practice", Journal of Competition Law and Economics 10 (2014): 293339; Bundeskartellamt, "Working Paper. The Market Power of Platforms and Networks", 39-41.

${ }^{28}$ See Miguel Sousa Ferro, "'Ceci n'est pas un Marché': Gratuity and Competition Law”, accessed July 2, 2017, https://papers.ssrn.com/sol3/papers.cfm?abstract_id=2493236.

${ }^{29}$ See Sébastien Broos and Jorge Marcos Ramos, "Google, Google Shopping and Amazon: The Importance of Competing Business Models and Two-Sided Intermediaries in Defining Relevant Markets", accessed July 2, 2017, https://papers.ssrn.com/sol3/papers.cfm?abstract_id=2696045.
} 
achieved by the product offered free of charge. There is a linkage between both sides which cannot be captured by the definition of a relevant product market consisting in a free service.

The need to take into account the interdependence between the two sides of the platform is even more evident in the case of transaction platforms, which connect distinct groups of users for a specific transaction. As the members of each group benefit from the growth of the other group, there are bilateral indirect network effects. In this case, it seems even more appropriate to define only one market -i.e., the market in the intermediation related to the underlying product or service- without considering each market side separately. ${ }^{30}$ The key activity of an online transaction platform is to act as an intermediary between providers and demanders, bringing the two sides together. The product is, thus, indivisible and has to include both groups of users. Even from the perspective of the demand side's substitutability, the possibilities of each user group to switch providers - to a non-digital intermediary, for example - are essentially the same, and both user groups would have to be brought together again. ${ }^{31}$ In this sense, the Commission considered in Travelport/Worldspan that the relevant market was the market for electronic travel distribution services through a global distribution system (GDS), which act as intermediaries in a two-sided market connecting two different customer categories; i.e., travel service providers (airlines, car rental companies and hotel chains) and travel agencies. ${ }^{32}$ Similarly, in Google/Doubleclick, the Commission established a market for intermediation in online advertising. ${ }^{33}$ However, it is questionable if this remains the point of view of the Commission, since subsequently it has been explicitly rejected when analysing other types of platforms. ${ }^{34}$

\footnotetext{
${ }^{30}$ See Lapo Filistrucchi, Damien Geradin, Erin van Damme and Pauline Affeldt, "Market Definition in Two-Sided Markets: Theory and Practice", Journal of Competition Law and Economics 10 (2014): 316; Bundeskartellamt, "Market Power of Platforms", 28-29; Guy Lougher and Sammy Kalmanowicz, "EU Competition Law in the Sharing Economy", Journal of European Competition Law and Practice 7 (2016): 87-102.

${ }^{31}$ This approach has been adopted by the Bundeskartellamt when assessing the mergers of online real estate platforms (B6-39/15, Immonet/Inmowelt ) and online dating platforms (B6-57/15, Oakley Capital/ EliteMedianet), and by the Spanish CNMC when assessing the merger of apps providers for the intermediation in taxi services (C/0802/16 Daimler/Hailo/Mytaxy).

${ }^{32}$ M.4523 - Travelport/Worldspan.

${ }^{33}$ Google/DoubleClick, 44-56.

${ }^{34}$ See Commission Decisions of 3 October 2008, COMP/M.5241 - AMERICAN EXPRESS/ FORTIS/ ALPHA CARD, and 8 December 2010, COMP/39.398 - Visa MIF. In both cases it essentially returned to the approach of its Decision of 17 October 2007, COMP/D1/38606 - Groupement
} 
The precise relevant product market definition is considered less important than making sure that the interdependence between the two sides is adequately taken into account. ${ }^{35}$ However, the Commission defines as many markets as the products being offered to each group, even if they are offered free of charge, and subsequently assesses the competitive position of the platform independently in each of them. This could lead to erroneous results if the said interdependence is ignored.

\section{Network effects as a barrier to entry or expansion}

A merger is unlikely to impede effective competition when entering the market is sufficiently easy. Entry constitutes a competitive constraint on the merging parties as long as it is likely, timely and sufficient to deter or defeat any potential anti-competitive effects of the merger. It is less likely if potential entrants may encounter barriers to entry; i.e., specific features of the market that give incumbent firms advantages over potential competitors, since they determine entry risks and costs and thus have an impact on the profitability of entry. Therefore, network effects are considered as a potential barrier to entry or expansion, which thus constitutes an important element of the overall competitive assessment. ${ }^{36}$ As the Federal Trade Commission has recently stated, "two-sided network effects may enable a large platform to become dominant and insulated from competition from smaller platforms with fewer participants. Because they afford buyers and sellers fewer transacting options, smaller platforms may be far less attractive than a larger platform, limiting the extent to which they serve as viable competitive alternatives. Two-sided network effects could also create a barrier to entry, thereby protecting a dominant incumbent from a new entry. A new platform would be unappealing to buyers unless it has attracted numerous participating sellers, and unappealing to sellers unless it has attracted numerous participating buyers. In other words, it must solve the chicken-and-egg problem noted earlier" ${ }^{37}$ In the case of digital platforms, access to a large volume or variety of data may be necessary as well to compete on the market. This need may reinforce the network effects, since the

des Cartes Bancaires, paragraph 180, where it stated that the "two-sided" nature of an economic activity by no means signifies that the system concerned constitutes a single market.

${ }^{35}$ OECD, "Policy Roundtables: Two-Sided Markets", 11.

${ }^{36}$ See Horizontal Guidelines, paragraphs 68-75.

${ }^{37}$ Federal Trade Commission, "The 'Sharing' Economy. Issues Facing Platforms, Participants \& Regulators" (2016): 26. 
collection of data may result in entry barriers when new entrants are unable either to collect the data or to buy access to the same volume and variety of data as established companies. ${ }^{38}$

In this sense, the Commission has previously established that network effects determine that entry in digital multi-sided markets might only be economically viable on a large scale, thus rendering the entry unprofitable unless the entrant can obtain a sufficiently large market share and leading to a higher level of concentration in the market, which may become inefficiently locked-in to an inferior technology ${ }^{39}$ However, it has subsequently adopted a less categorical approach in merger cases. In Facebook/ WhatsApp and Microsoft/LinkedIn it has recognised that "the existence of network effects as such does not a priori indicate a competition problem in the market affected by a merger. Such effects may however raise competition concerns in particular if they allow the merged entity to foreclose competitors and make it more difficult for competing providers to expand their customer base. Network effects have to be assessed on a case-by-case basis". ${ }^{40}$ Therefore, the mere existence of network effects does not represent automatically an entry barrier.

Network effects - as market power - are a matter of degree. ${ }^{41}$ To become an entry barrier in the sense of the EU merger control, the strength of network effects must reach a sufficient level, which is not easily measured and may vary according to the particular features of the relevant market. From the recent practice of the Commission, it seems possible to identify some relevant factors: the interoperability of the network, its type of use and its function.

\footnotetext{
${ }^{38}$ See the Joint Paper of the Autorite de la Concurrence and the Bundeskartellamt on Competition Law and Data (2016): 11, accessed July 2, 2017, http://www.bundeskartellamt.de/SharedDocs/ Publikation/DE/Berichte/Big\%20Data\%20Papier.pdf?__blob=publicationFile\&v=2.

${ }^{39}$ See Commission Decision of 24 March 2004 relating to a proceeding under Article 82 of the EC Treaty (Case COMP/C-3/37.792 Microsoft): paragraphs 448-464. See Maurice E. Stucke and Ariel Ezrachi, "When Competition Fails to Optimize Quality: A Look at Search Engines", Yale Journal of Law and Technology 18 (2016): 70-110.

${ }^{40}$ Facebook/Whatsapp, paragraph 130; Microsoft/LinkedIn, paragraph 342.

${ }^{41}$ David S. Evans and Richard Schmalensee, "The Industrial Organization of Markets with TwoSided Platforms", Competition Policy International 3, no. 1 (2007): 150-179, 173.
} 


\subsection{The incompatibility of the network}

In horizontal cases, network effects arise or are reinforced as a direct consequence of the notified merger when the respective networks of the merging firms are compatible or interoperable with one another. Otherwise, the installed bases of each of them cannot be added, and the preexisting network effects are therefore not increased. In this sense, in Facebook/ WhatsApp the Commission noted that the proposed transaction was not likely to lead to any merger-specific substantial strengthening of network effects, since it was not possible to combine the separate user networks of WhatsApp and Facebook into one, substantially larger network, due to technical and commercial reasons. In addition, even if some kind of interoperability between them were to take place, there was already a significant overlap between the networks of WhatsApp and Facebook. Therefore, preexisting network effects would be unlikely to be substantially strengthened by the proposed merger. ${ }^{42}$

Furthermore, when the merging firms compete in the same relevant market, the addition of their market shares may lead to an increased market power. However, network effects represent a competitive advantage and thus an entry barrier - only as long as the platform or network remains not fully compatible with those of their competitors. Otherwise, all of them would benefit from the same network effects, since it is as if there was only one network. ${ }^{43}$ Consequently, larger firms have fewer incentives to make their network compatible with the immediate consequence of creating a unique network. ${ }^{44}$

The same reasoning is equally applicable to non-horizontal (i.e., vertical or conglomerate) mergers. Although they do not entail the loss of direct

\footnotetext{
${ }^{42}$ See Facebook/WhatsApp paragraphs 123, 136-140. Based on the information provided by the merging parties, the Commission considered that technical integration between WhatsApp and Facebook was unlikely due to technical difficulties. However, it subsequently found that, contrary to Facebook's statements, that technical possibility already existed in 2014 and hence fined Facebook for providing incorrect or misleading information. See Antonio Robles Martín-Laborda, "Sexo, Mentiras y Efectos de Red. Sobre la Compra de WhatsApp por Parte de Facebook", Competencia y Regulación, accessed July 2, 2017, http://derechocompetencia.blogspot.com.es/2017/01/sexo-mentiras-y-efectos-de-red.html.

${ }^{43}$ See Bruno Jullien and Wilfried Sand-Zantman, "Network Effects", Institut D'Economie Industrielle (June 2016): 9, accessed July 2, 2017, https://idei.fr/sites/default/files/IDEI/documents/ conf/trading2016/rapport/network_effect.pdf

${ }^{44}$ See Commission Decisions of 8 June 2000 (Case No COMP/M.1741 - MCI WorldCom / Sprint), paragraph 154, and 24 March 2004 relating to a proceeding under Article 82 of the EC Treaty in Case COMP/C-3/37.792, Microsoft.
} 
competition between the merging firms and provide substantial scope for efficiencies, there are circumstances in which a non-horizontal merger may significantly impede effective competition when it gives rise to foreclosure, hampering actual or potential rivals' access to supplies or markets. ${ }^{45}$ According to the Commission, conglomerate mergers can exceptionally lead to foreclosure when the combination of products in related markets may confer on the merged entity the ability and incentive to leverage a strong market position from one market to another closely related market by means of tying, bundling or other exclusionary practices as refusal to deal. ${ }^{46}$ Tying and bundling as such are considered common practices usually designed to provide better products or offerings. However, in presence of network effects the dominance over one product is more likely to create dominance over another complementary product. Therefore, larger firms have strong incentives to make their network incompatible through tying, bundling or refusal to deal. By degrading the interoperability of the network (i.e., impeding full compatibility), in certain circumstances they may lead to a reduction in actual or potential rivals' ability or incentive to compete, thus reducing the competitive pressure on the merged entity and allowing it to increase prices. In these cases as well, the competitive advantage derived from the network effects requires that the network created or strengthened in the related market as a consequence of the leveraged market position was not fully compatible with the preexisting networks. ${ }^{47}$

In this sense, in Microsoft/Skype the Commission assessed whether postmerger Microsoft could adopt some strategy to leverage Microsoft's or Skype's strong position in their respective markets. Microsoft, for example, could degrade the interoperability of Windows with competing providers of consumer communications services in order to favour Skype, and

${ }^{45}$ See Non-Horizontal Guidelines, paragraphs 12-18.

${ }^{46}$ See Non-Horizontal Guidelines, paragraphs 91-93. In the United States, the recent announcement of the acquisition of Whole Foods by Amazon has raised some antitrust concerns. The transaction might give the acquirer access to relevant data and some support in relation to the usual chicken-and-egg problem, although it is a vertical merger with no plausible input or output foreclosure. But see Lina M. Kahn, “The Amazon Paradox", Yale Law Journal, 126 (2017): 710-805, accessed July 2, 2017: https://ssrn.com/abstract $=2911742$. Under EU competition law, a vertical merger may lead to foreclosure where it is likely to raise the costs of downstream rivals by restricting their access to an important input (input foreclosure) or by restricting their access to a sufficient customer base (costumer foreclosure). See Non-Horizontal Guidelines, 29-77.

${ }^{47}$ See Suzanne Van Arsdale \& Cody Venzke, "Predatory Innovation in Software Markets", Harvard Journal of Law \& Technology 29 (2015): 243-290; Thibault Schrepel, "Predatory Innovation: The Definite Need for Legal Recognition” accessed July 21, 2017: https://ssrn.com/abstract=2997586. 
consequently leverage its market power from the OS market to the consumer communications market. The Commission also assessed whether Microsoft could decide to integrate (i.e. tying) Skype with Windows or Office, but considered - erroneously, as time has shown ${ }^{48}$ - that Microsoft had no incentives to enter into either of those practices. Furthermore, the effects of a foreclosure strategy would be almost non-existent, since Skype was already pre-installed on a significant share of Windows-PCs sold to consumers. $^{49}$

The Commission reached a different conclusion in Microsoft/LinkedIn, whether due to the different features of the professional social networking services (PSN) or to a more concerned assessment of the incentives of merging platforms. Microsoft had very high market shares in the markets for OSs for PCs and productivity software for PCs in the EEA. The Commission recalled that the existence of network effects as such does not a priori indicate a competition problem, unless they allow the merged entity to foreclose competitors and make it more difficult for competing providers to expand their customer base. In this case, however, it considered that the merged entity could have the ability and the incentive to leverage its strong market position from those markets to the market for PSN services by preinstalling a LinkedIn application on Windows PCs and by integrating LinkedIn into Office, while denying access to Microsoft application programming interfaces (APIs); i.e., degrading compatibility between networks. The subsequent LinkedIn's growth and the negative impact on competing PSN providers could be further enhanced by virtue of the network effects that characterise the market for PSN services. Indeed, the Commission noted that professionals tend to benefit as more professionals join the network and use it actively, since this is likely to translate into a higher number of professional contacts, of profile views and of recruitment opportunities. Therefore, it appeared likely that network effects could

\footnotetext{
${ }^{48}$ See, for example, Alfonso Lamadrid, "Déjà Vu? Microsoft Announces Skype's Integration in Windows", Chillin' Competition, 2 September 2013, https://chillingcompetition.com/2013/09/02/ deja-vu-microsoft-announces-skypes-integration-in-windows/.

${ }^{49}$ See Microsoft/Skype, paragraphs 134-170. Regarding this aspect, the Commission also noted that Skype was currently a closed system, since it was not possible for consumers to communicate between Skype and competing communications services such Viber. The Commission stressed the fact that the notified merger had no effect on the lack of interoperability of Skype. In fact, as stated above, the interoperability of Skype with other communications services had been as if there was only one network, consequently Microsoft had lost any competitive advantage derived from the network effects.
} 
potentially strengthen the foreclosure of competing providers of PSN services. ${ }^{50}$ The transaction was finally cleared subject to full compliance with the obligations contained in the commitments submitted by the notifying party, meant to address the Commission's compatibility concerns relating to the possible integration of LinkedIn features into Office along with the possible denial of access to Microsoft APIs, and to the possible pre-installation of a LinkedIn application on Windows PCs. ${ }^{51}$

Interoperability is therefore recognised as a fundamental value in European competition policy. ${ }^{52}$ Consequently, the Commission examines whether the merged firm would have the ability to foreclose its rivals, whether it would have the economic incentive to do so and whether a foreclosure strategy would have a significant detrimental effect on competition, thus causing harm to consumers. ${ }^{53}$ When these requirements are met, it may rely on interoperability remedies to address the risk of foreclosure created by a notified transaction. ${ }^{54}$ Competition authorities, however, should take into account that the increased compatibility as a consequence of remedies generates more satisfaction for customers ex post $t_{2}$ but it might lower the incentive to aggressively invest to build an installed based (i.e., to subsidise the users' side) ex ante, thus slowing the introduction of the new technology. ${ }^{55}$

\subsection{The type of use of the network}

Platforms can usually differentiate themselves from each other by choosing particular levels of quality, features or prices, thus appealing to different groups of customers. ${ }^{56}$ Since participation in most platforms is frequently free or not too costly, it does not preclude that at least some members of one side of the market may find it easy to participate on several platforms simultaneously (i.e., to "multi-home"). ${ }^{57}$ Whenever there are several

\footnotetext{
${ }^{50}$ Microsoft/LinkedIn, paragraphs 278-352

${ }^{51}$ Microsoft/LinkedIn, paragraphs 407-470.

${ }^{52}$ See Christopher Thomas, "Intel and McAfee - Antitrust is 'Getting it Right' in High Tech", CPI Antitrust Journal, January 2011 (2), 3.

${ }^{53}$ See Non-Horizontal Guidelines, paragraph 94.

${ }^{54}$ See Inge Graef, "How Can Software Interoperability be Achieved under European Competition Law and Related Regimes?", Journal of European Competition Law \& Practice 5 (2014): 6-19.

${ }^{55}$ See Bruno Jullien and Wilfried Sand-Zantman, "Network Effects", 11-12.

${ }^{56}$ See David S. Evans and Richard Schmalensee, "The Industrial Organization of Markets with Two-Sided Platforms", 164-166.

${ }^{57}$ See Jean-Charles Rochet and Jean Tirole, "Platform Competition in Two-Sided Markets", 991993.
} 
providers of the same type of platform with some degree of differentiation, customers on each side of the platform may choose to subscribe to one provider only ("single-homing") or to several providers ("multi-homing") depending on several factors, as the degree of asymmetry of the network effects on the different sides of the platform, the degree of differentiation between competing platforms or the cost to switch between platforms.

In Travelport/Worldspan, the merging entities operated in the market for electronic travel distribution services through a global distribution system (GDS), acting as intermediaries between travel service providers (TSPs) (airlines, car rental companies and hotel chains) and travel agencies (TAs). In this case, the number of "reachable" TAs was important for the TSPs, due to the network externalities generated on the TA side. Therefore, multi-homing was important for the TSPs. Since almost every TSP used multi-homing, the network externalities on the TSP side were reduced (multi-homing did not allow TAs to reach more TSPs), making singlehoming the most viable option for TAs. In this sense, the Commission noted that "a TSP targeting a given geographic market will, in order to maximise the coverage of end-consumers, provide content to all GDS providers offering an effective distribution channel in that geographic market. The TSP will therefore opt for multi-homing by distributing its inventory via all (geographically relevant) GDS providers. However, given the fact that contracts between GDS providers and TSPs are normally concluded on a global basis, TSPs will tend to subscribe to all GDS providers. If a sufficient number of TSPs use multi-homing (which means that each GDS provides a broadly similar content), TAs will only need to subscribe to one GDS, because the added value of subscribing to a second GDS will be close (or equal) to zero (therefore not off-setting the additional costs generated by subscribing to two instead of one GDS" ${ }^{58}$

Conversely, in the case of professional social network services (PSN), the Commission noted that actively engaging on a PSN platform usually requires significant time on the part of PSN users, since they have to curate and update their profiles as well as to build and interact with new contacts. This cost disincentivises multi-homing between PSN platforms. In this way, although launching a new PSN service may not necessarily entail significant costs, the need to achieve a sizeable user base constituted a high,

\footnotetext{
${ }^{58}$ Travelport/Worldspan, paragraph 17.
} 
sometimes unsurmountable, barrier to entry. ${ }^{59}$ Since multi-homing was unlikely, the Commission concluded that the risk of foreclosure through the degradation of compatibility, stemming from the pre-installation of a LinkedIn application on Windows PCs and the integration of LinkedIn features into Office, in combination with the denial of access to Office APIs, would have a negative impact on effective competition in the markets for PSN services and online recruitment services in the EEA. ${ }^{60}$

Multi-homing has also been considered a factor which mitigates the role of network effects in impeding entry or expansion in Facebook/Whatsapp. The Commission established that "the use of one consumer communications app (for example, of the merged entity) does not exclude the use of competing consumer communications apps by the same user. A majority of users of consumer communications apps in the EEA have installed and are using two or more consumer communications apps. Multi-homing is facilitated by the ease of downloading a consumer communications app, which is generally free, easy to access and does not take up much capacity on a smartphone. Also, using multiple consumer communications apps is easy, since a user does not have to log in each time, when switching an app, and the messages are "pushed" (that is, delivered automatically) onto a user's device. Hence, the fact that a large number of users will be on the merged entity's network is unlikely to preclude them from also using competing consumer communications apps" ${ }^{61}$

As stated above, in both horizontal and non-horizontal mergers network effects only represent an entry barrier - i.e., a competitive advantage - as long as the network of the merging entity is not fully compatible with the competing networks. However, multi-homing may reduce barriers to entry or expansion and it has consequently been considered, at least to a limited extent, a substitute of compatibility. ${ }^{62}$ Since users do not need to abandon the other networks, entry is much easier in markets where they multihome. Therefore, the form of use of the platform or network has considerable relevance for assessing the existence of market power.

\footnotetext{
${ }^{59}$ Microsoft/LinkedIn, paragraphs 345-346.

${ }^{60}$ Microsoft/LinkedIn, paragraphs 278-368.

${ }^{61}$ Facebook/Whatsapp, paragraph 133. See also Microsoft/LinkedIn, paragraph 92.

${ }^{62}$ See Bruno Jullien and Wilfried Sand-Zantman, "Network Effects", 16; Toker Doganoglu and Julian Wright, "Multihoming and Compatibility", International Journal of Industrial Organization 24 (2006): 45-67.
} 


\subsection{The function of the network}

Since a network is a system of nodes - whether it be airports, cities, computers or customers - connected by edges or links, ${ }^{63}$ the strength of network effects as an entry barrier also depends on the number and the intensity of the relevant links among its users. ${ }^{64}$ Therefore, when the market is expected to experience high growth in the future, the relatively small number of existing links in relation to the potential size of the network may consequently lead to consider the entry more likely to be profitable. ${ }^{65}$

In this sense, the Commission has considered that "the network effects are mitigated by the fact that most consumers of communications services make the majority of their voice and video calls to the small number of family and friends that make up their so-called "inner circle". According to Facebook data, users engage in regular two-way interaction with four to six people. Therefore, it is not difficult for these groups to move between communications services. The existence of low barriers to expansion is illustrated by the fast growth in terms of active users of recent new entrants in the consumer communications services markets. ${ }^{66}$ Conversely, in relation to the social network market, the Commission established that "it appears likely that network effects could potentially strengthen the foreclosure of competing providers of PSN services that currently exist in certain EEA countries or of potential new entrants. According to the concerns put forward by certain respondents to the market investigation, as the number of members of LinkedIn grows, additional users would be induced to join LinkedIn and to generate activity on its platform. By contrast, increasingly fewer users may be induced to join competing PSN service providers, as those providers would become less attractive in terms of size of their

\footnotetext{
${ }^{63}$ See M. E. J. Newman, "The Structure and Function of Complex Networks", 1-4, accessed July 2, 2017: http://www-personal.umich.edu/ mejn/courses/2004/cscs535/review.pdf; Maarten van Steen Version, An Introduction to Graph Theory and Complex Networks (2010):1.3-1.13, accessed July 2, 2017: https://pdfs.semanticscholar.org/9dba/e30f8253791138e6c1031c5b7e4c7b321185.pdf. ${ }^{64}$ On the different weights associated with ties in terms of their strength, intensity or capacity, see Andrea Petróczi, Tamás Nepusz and Fülöp Bazsó, "Measuring Tie-Strength in Virtual Social Networks", Connections 27 (2007): 39-52, accessed July 2, 2017: http://www.insna.org/PDF/ Connections/v27/2006_I-2-5.pdf. At present, there are no established methods to measure the impact of network effects on different platforms. A parameter comparable to a percentage in market share which might be useful for network effects is the so-called "unique visitor", which is a standard parameter often compiled in the market to express the intensity of a platform's usage. See Bundeskartellamt, "Market Power of Platforms and Networks", 50.

${ }^{65}$ See C/0802/16 Daimler/Hailo/Mytaxy.

${ }^{66} \mathrm{Microsoft} / \mathrm{Skype}$, paragraph 92. See Horizontal Guidelines, paragraph 72.
} 
networks and recruitment opportunities. As a result, this could lead to a slowing down in the growth of competing PSNs' member bases and eventually to a decline in the activity of competing PSNs' actual members, who would instead become active on LinkedIn. This trend could continue up to the point where the market would 'tip' in favour of LinkedIn's network and LinkedIn's already strong position would become entrenched". ${ }^{67}$

Communication networks enable direct communication between users who usually already know each other. Social networks, on the contrary, may facilitate indirect communication or interaction between users who did not know each other beforehand. ${ }^{68}$ Therefore, the scope of network effects may vary depending on the intensity and the number of the relevant links among its users, which are determined by the function of the network.

\section{Indirect network effects and power over price}

While indirect network effects might contribute to the increase of the level of concentration in the relevant market, the existence of demand interdependencies entails certain particular competitive features related to the ability of the platform to profitably increase prices over marginal costs. In particular, the link between the users of distinct sides affects the price elasticity of demand and, consequently, the profitability of a price increase on either side of the platform. Taking both sides of the market into account is thus also important for analysing market power.

As stated above, the interdependency between the distinct sides of online platforms means that the adjustment of the price charged to one group of users affects the demand level of the other groups. Price structure (i.e., the way prices are distributed between customers on the different sides of the market) is non-neutral, in the sense that it affects the level of transactions. The platform may influence the production level not only changing the price level, but also its structure, charging more one side of the market and reducing the price paid by the other side. An increase in the price (or a reduction of quality) to one side reduces the value that the costumers of other sides receive from the platform, which, in turn, can reduce the demand and price they are willing to pay. Therefore, the platform must design the price structure so as to induce both sides to join the platform. ${ }^{69}$

\footnotetext{
${ }^{67}$ Microsoft/LinkedIn, paragraph 343.

${ }^{68}$ See Bundeskartellamt, "Market Power of Platforms and Networks", 100-101.

${ }^{69}$ See Jean-Charles Rochet and Jean Tirole, "An Economic Analysis of the Determination of Interchange Fees in Payment Card Systems", Review of Network Economics, no. 2 (2003): 69-71,
} 
The linkage between its different groups of customers thus affects the ability of the platform to profitably increase prices (i.e., it imposes a constraint on the market power) and may lead the profit maximizing price to differ substantially from marginal cost. Therefore, "the price on one side of the market could be well above marginal cost while the price on the other side of the market could be below marginal cost. To analyze market power one therefore has to examine whether the total price is significantly above marginal costs". ${ }^{70}$

While the assessment of the competitive position of the platform in each side of the market cannot be done independently, the profitability of a price increase on either side of the platform may vary according to the existing type of indirect network effects.

\subsection{Bilateral network effects}

In the case of transaction platforms, which connect distinct groups of users for a specific transaction, there are bilateral indirect network effects; i.e., the members of both groups benefit from the growth of the other group. Since the product is indivisible and has to include both groups of users, the interdependence of the two sides of the platform must be adequately taken into account. In this sense, marginal revenue associated with any new customer has a direct component if it generates revenues in form of fees, and an indirect component by increasing the value of the platform to consumers on the other side, thus enabling the platform to charge more to them. While the group of consumers that generates the highest level of indirect network effects might be charged a price well below marginal cost, consumers on the other side will be charged prices considerably above marginal cost. ${ }^{71}$ In this way, the type of use of the platform affects its ability to profitably increase prices.

\section{(a) Multi-homing on one side}

If single-homing prevails on one side while the other predominantly practices multi-homing, existing market power would be assumed for

accessed July 2, 2017: https://www.researchgate.net/publication/24049673_An_Economic_ Analysis_of_the_Determination_of_Interchange_Fees_in_Payment_Card_Systems; OECD, "Two-Sided Markets", 11.

${ }^{70}$ David S. Evans, "The Antitrust Economics of Two-Sided Markets", 65, accessed July 2, 2017: https://papers.ssrn.com/sol3/papers.cfm?abstract_id=332022.

${ }^{71}$ OECD, "Policy Roundtables: Two-Sided Markets", 12. 
the multi-homing side if both market sides are considered separately. Platforms that serve large portions of users who predominately practice single-home might be considered virtually indispensable for the other user side, especially taking into account the asymmetrical pricing strategy. While the multi-homing side pays considerably higher fees or is the only side paying fees at all, more favourable conditions or even free services may often be found on the single-homing side, where intensive competition may actually be established as platforms need to poach these single-homing users from each other in order to get them to join their own platform. ${ }^{72}$ In this sense, the Commission tends to ignore the constraints that the key activity of an online transaction platform (i.e., to act as an intermediary between providers and demanders) imposes upon its ability and incentives to increase prices in order to get the two sides together.

In Travelport/Worldspan, the merging entities operated in the market for electronic travel distribution services through a global distribution system (GDS), acting as intermediaries between travel service providers (TSPs) (airlines, car rental companies and hotel chains) and travel agencies (TAs). The resulting firm would have a strong market position in the TAs' side of some national markets (the single-homing side). The Commission was concerned with its ability to leverage its post-merger market power in a number of national TAs markets in order to strengthen its market power in the TSPs side (the multi-homing side). Such "vertical cross-market effect" would permit the combined entity to use its market power in the TAs' side to gain concessions from the TSP when negotiating a worldwide agreement, possibly allowing it to raise prices unilaterally post-merger. The Commission concluded that in "such a situation, the GDS providers have strong incentives to maintain and expand their TA network by providing financial assistance to TAs and recoup that investment (and generate their margin) by extracting rents upstream from the TSPs. The merged undertaking thus has an incentive to translate high downstream market shares into unilateral price increases upstream" ${ }^{73}$ Therefore, the Commission disregards the fact that, since the adjustment of the price charged to one group of users affects the demand level of the other groups, the platform must design the price structure so as to induce both sides to join the platform. ${ }^{74}$ In this sense, while GDSs did not compete fiercely for the users that practice

\footnotetext{
${ }^{72}$ See Bundeskartellamt, "Market Power of Platforms and Networks", 63-64.

${ }^{73}$ Travelport/Worldspan, 73-81.

${ }^{74}$ OECD, “Policy Roundtables: Two-Sided Markets", 11.
} 
multi-homing (TSPs), strong competition took place on the single-homing side (TAs). ${ }^{75}$ The position of the platform faced to TSPs was thus erroneously considered a "potentially detrimental effect of the merger in terms of the potential occurrence of vertical cross-market effects" that had to be finally considered countervailed by some recent market developments, ${ }^{76}$ although the Commission had previously recognised that the "monopoly rents' extracted from TSPs are to a large extent used to cover the financial incentives granted to TAs" ${ }^{77}$ If this was the case, however, the over-price charged to the multi-homing side could not be considered "monopoly rents". The merging entity was not exercising its (lacking) market power to increase prices, but its bargaining power in one market to compete on the merits in the other. ${ }^{78}$

\section{(b) Multi-homing on both sides}

Taking account of the interdependence of the two sides of the platform, market power of a platform is even more unlikely when multi-homing along with platform differentiation - prevails on both sides. On the contrary, separating the two sides of the market without taking account of their interdependence allows legitimate competitive activities in one of them to be penalised no matter how output-expanding such activities may be. In order to retain users of one side, a platform may need to increase their benefits - or, viewed another way, "decrease their prices" -, which may call for an increase in fees on the other side to fund the increased rewards. Therefore, increases in one side's fees are a concomitant of a successful investment in creating output and value. An increase in the value of the rewards of one group of users -which attracts customer loyalty is "equivalent to a price decrease", and thus it brings down the net price across the entire platform. A firm that can attract customer loyalty only by reducing its prices does not have the power to increase prices unilaterally. By attracting users on one side, the platform delivers a significant benefit to service providers on the other: customers. ${ }^{79}$ Therefore, since market power

\footnotetext{
${ }^{75}$ See Bruno Jullien, "Two-Sided Markets and Electronic Intermediaries", CESifo Economic Studies 51, no. 2-3 (2005): 233-260, also accessible at https://ideas.repec.org/p/ces/ceswps/_1345.html.

${ }^{76}$ Travelport/Worldspan, 82-101.

77 Travelport/Worldspan, 81.

${ }^{78}$ On the difference between buyer power and bargaining power, see Ignacio Herrera Anchústegui, Buyer Power in EU Competition Law (Bergen: University of Bergen, 2017): 51-52.

${ }^{79}$ See United States v. American Express Co., No. 15-1672 (2d Cir. 2016). In relation to credit cards as well, the Court of Justice has taken into account the linkage between the different sides of the
} 
is the ability to increase prices through the reduction of output, when the extra charge applied to one group of users of the platform is used to promote the demand of the users of the other group, in such a way that total output increases, the price increase in one side of the platform should not be considered a sign of market power. ${ }^{80}$

\subsection{Asymmetric network effects}

Audience providing platforms offer services and contents usually free of charge (e.g. search engines, social network services) to users on one side, which constitute the target of the advertising space offered for a price to the advertisers on the other side. The same principles applicable to the assessment of matching platforms are also relevant in the case of audience providing platforms, as long as the fact that indirect effects are unilateral or asymmetrical - i.e., they are present in only one direction - is taken into account. ${ }^{81}$ Asymmetric network effects may lead to market concentration, both on the advertising side and the service side. However, while the advertising side profits from a large group of service users, the latter would not directly profit from more advertising and, therefore, there will be no selfreinforcing positive feedback loops leading to a tipping process. ${ }^{82}$

Since the advertising side profits from a large group of service users, it has been considered that strong indirect network effects produced by an extremely wide platform reach may actually make it indispensable for the advertising side. ${ }^{83}$ The Commission did not exclude that possibility in

platform, establishing that "in a card payment system that is by nature two-sided, such as that of the Grouping, the issuing and acquisition activities are 'essential' to one another and to the operation of that system: first, traders would not agree to join the CB card payment system if the number of cardholders was insufficient and, secondly, consumers would not wish to hold a card if it could not be used with a sufficient number of traders [...] there were 'interactions' between the issuing and acquisition activities of a payment system and that those activities produced 'indirect network effects', since the extent of merchants' acceptance of cards and the number of cards in circulation each affects the other [...]". See Judgment of 11 September 2014, Groupement des Cartes Bancaires (CB), C67/13 P, EU:C:2014:2204, paragraph 74.

${ }^{80}$ See Julian Wright, "One-Sided Logic in Two-Sided Markets", Revue of Network Economics, 3 (2004): 44-64; David S. Evans and Richard Schmalensee, "The Industrial Organization of Markets with Two-Sided Platforms", 173-174.

${ }^{81}$ See David S. Evans, "Multisided Platforms, Dynamic Competition, and the Assessment of Market Power for Internet-Based Firms", University of Chicago Coase-Sandor Institute for Law \& Economics Research Paper No. 753, 23-31, accessed July 2, 2017: https://papers.ssrn.com/sol3/ papers.cfm?abstract_id $=2746095$.

${ }^{82}$ Bundeskartellamt, 51-52.

${ }^{83}$ Bundeskartellamt, 52. 
Google/DoubleClick ${ }^{84}$ given the strong market position that Google had in the segment of online search advertising. ${ }^{85}$ However, it found that the merged entity would not have an incentive to adopt a foreclosure strategy because it would be not profitable. ${ }^{86}$ This means that Google did not enjoy enough market power. Consequently, "such a strategy would be very unlikely to have a significant detrimental effect on competition. As recognised by the Non-Horizontal Merger Guidelines, it is only when a sufficiently large fraction of market output is affected by foreclosure resulting from the merger that the merger may significantly impede effective competition. If there remain effective players in either market, competition is unlikely to deteriorate" ${ }^{87}$ Furthermore, potential negative indirect network effects towards service users have to be considered, since they affect market power on the advertising side by limiting advertising capacities that platforms are able to offer to advertisers. ${ }^{88}$ The type of use of the platform is also relevant, since online advertisers tend to multi-home. Different model businesses compete in online advertising market, where there are "a sufficient number of alternative providers of online advertising services" and "a large amount of Internet user data that are valuable for advertising purposes" ${ }^{89}$ Multi-homing thus constitutes a factor that mitigates barriers to market entry on the advertising market. An increase in the demand of search engines could affect the sales of a firm offering social networks, and vice versa. Therefore, although they present different business models, both might be considered competitors for advertisers in the market of online advertising (the paying side of the platform).$^{90}$

As the service users' side does not directly profit from more advertising on the other side, it thus would grow only as a consequence of the

\footnotetext{
${ }^{84}$ Google/DoubleClick, 337-345.

${ }^{85}$ In the advertising side, the Commission has distinguished between the provision of online and offline advertising space, leaving open the question of whether the market for online advertising could be sub-segmented into search and non-search advertising. See Commission Decision of 18 February 2010 in Case M.5727 - Microsoft/Yahoo! Search Business, paragraph 61; Google/ DoubleClick, paragraphs 45-46; 56; Facebook/Whatsapp, paragraphs 73-79; Commission Decision of 27 June 1017, M.39740 Google Search (Shopping) (not yet published).

${ }^{86}$ Google/DoubleClick, 346-355.

${ }^{87}$ Google/DoubleClick, 356.

${ }^{88}$ Bundeskartellamt, 52.

${ }^{89}$ Facebook/Whatsapp, paragraphs 188-189.

${ }^{90}$ See Sébastien Broos and Jorge Marcos Ramos, "Google, Google Shopping and Amazon: The Importance of Competing Business Models and Two-Sided Intermediaries in Defining Relevant Markets", accessed July 2, 2017, https://papers.ssrn.com/sol3/papers.cfm?abstract_id=2696045.
} 
intrinsic value of the service and, as the case may be, of direct network effects. Network effects might constitute a barrier to entry or expansion whose role can also in this case be mitigated by multi-homing. Therefore, to assess the market power of the firm on the users' side it is also relevant to consider whether users practice single-homing or multi-homing, which in turn depends on the degree of differentiation that can be attained. In this sense, the Commission has considered that in the market for social network services there are a large number of companies offering online services highly differentiated in their nature and focus, and designed with different features and for different aims (e.g. keeping in touch with friends and family, establishing professional contacts, sharing content). Since there is a high degree of differentiation between providers, users of social networks tend to multi-home. Therefore, market power on the users' side is not likely. ${ }^{91}$ Conversely, the services provided by search engines are not as easily differentiable and consequently, users tend to single-home. When this is the case, "free platform use could pose an obstacle to switching if the service proved to be 'good enough' for the users' purposes and they decided not even to switch to services of better quality". ${ }^{92}$ However, this obstacle would be caused by users' inertia, but not by network effects. ${ }^{93}$

\section{Efficiencies derived from network effects as a countervailing factor}

In view of the above, it is possible to conclude that network effects may lead to concentrated markets, but not necessarily to higher prices or reduced quality. On the contrary, online platforms reduce search and transaction costs and contribute to a broader supply and dynamic development of markets and competition. While an increase in concentration may lead to deadweight loss and allocative inefficiency in one-sided markets, in the case of two-sided markets the existence of indirect network effects across groups of consumers provides conceivably more scope for mergers to

\footnotetext{
${ }^{91}$ See Facebook/Whatsapp, paragraphs 147-158.

92 Bundeskartellamt, "Market Power of Platforms and Networks", 53. Apparently, this reasoning has been adopted by the Commission in Google Search (Shopping), not yet published. The Commission concluded that Google is dominant in each national market for general internet search throughout the European Economic Area (EEA), based on the fact that Google's search engine has held very high market shares and there are high barriers to entry in these markets, in part because of network effects. The question was not decided in Streetmap.EU Ltd v Google Inc. \& Ors [2016] EWHC 253 (Ch) (12 February 2016).

${ }^{93}$ See Commission Decision of 24 March 2004 (Case COMP/C-3/37.792 Microsoft): paragraph 870.
} 
generate transactional and productive efficiencies. ${ }^{94}$ When network effects exist, market dominance by a small number of firms does not always reduce consumer welfare because any loss of users' surplus from monopolization can be offset by an increased positive network effect. In this sense, the emergence of a dominant platform may maximise consumer welfare since "consumers are better off when they belong to a large network". ${ }^{95}$

Regulation 139/2004 explicitly clarified that the Commission should no longer limit its analysis to the structural outcome of the notified merger, but consider the effects it would have on consumer welfare. The substantive test based on structural dominance was replaced by the concept of a "significant impediment to effective competition", which calls upon the Commission to take account of "the development of technical and economic progress provided that it is to consumers' advantage and does not form an obstacle to competition". ${ }^{96}$ Therefore, efficiencies could be used as a defence to otherwise anticompetitive mergers. ${ }^{97}$ In this sense, when assessing "the impact of a concentration on competition in the common market, it is appropriate to take account of any substantiated and likely efficiencies put forward by the undertakings concerned. It is possible that the efficiencies brought about by the concentration counteract the effects on competition, and in particular the potential harm to consumers, that it might otherwise have and that, as a consequence, the concentration would not significantly impede effective competition, in the common market or in a substantial part of it, in particular as a result of the creation or strengthening of a dominant position". ${ }^{98}$ When a merger brings about substantial and timely efficiencies to the consumers' advantage - e.g. reductions in variable or marginal costs, new or improved products or services - there are no grounds for declaring the merger to be incompatible with the common market. ${ }^{99}$

\footnotetext{
${ }^{94}$ See, for a general approach to the different types of efficiencies and the trade-off between them, OECD Policy Roundtables, The Role of Efficiency Claims in Antitrust Proceedings (2012): 12-15.

${ }^{95}$ Bruno Jullien and Wilfried Sand-Zantman, "Network Effects", 16.

${ }^{96}$ Council Regulation 139/2004, of 20 January 2004, on the control of concentrations between undertakings, art. 2.1(b). An example of the "efficiency offence" allowed by the previous Council Regulation (EEC) No 4064/89 can be found in M.1795 Vodafone Airtouch/Mannesmann, paragraphs $42-43$.

${ }^{97}$ The way for a greater consideration of efficiencies in modern merger control was paved in Oliver E. Williamson, "Economies as an Antitrust Defense: The Welfare Tradeoffs", The American Economic Review 1 (1968): 18-36.

${ }^{98}$ Regulation 139/2004, recital 29.

${ }^{99}$ See Horizontal Guidelines, paragraphs 76-88.
} 
Since a monopolistic platform maximizes network effects, it has been considered that competition between platforms does not actually increase welfare. In fact, a higher number of platforms may decrease consumer welfare as the aggregate utility from network effects can be higher with a lower number of platforms. When network effects are present, a high level of concentration in the market can increase consumer surplus. Market concentration reinforces the network effects and, thus, consumer surplus. Even if prices for the services of a dominant platform are higher because of the lack of competition, the thickness provided by it may offer greater value to its users. ${ }^{100}$ In this sense, it has been considered that over-fragmentation constitutes a leading problem in platform industries, and that public policies should consequently seek to aid eventual efficient winners of platform competition in consolidating their dominant position as quickly as possible, and subsequently adopt appropriate forms of regulation of dominant platforms. ${ }^{101}$

The reinforcement of network effects that arise from a merger may enhance the ability and incentive of the merged entity to act pro-competitively for the benefit of consumers even when it becomes a monopoly, thereby counteracting the adverse effects on competition which the merger might otherwise have. A merger involving platforms "will affect the relative base of consumers on both sides of the market, and thereby the balance of indirect network externalities across the two sides of the market. This implies that the merger will affect not only the price level but also the price structure. Conceivably, the equilibrium post-merger prices could result in some prices increasing and others falling. In addition, if the merger increases the relative customer base on one side, it increases the value of belonging to the platform to the customers on the other side. Therefore, consumer welfare may increase even though prices increase on one side or in total". ${ }^{102}$

Certainly, the likely benefit of consumers depends on the incentive of the merged entity to pass efficiency gains on to them. In traditional markets this is often related to the existence of competitive pressure from the remaining firms in the market and from potential entry. In the case of online platforms, such pressure exists when at least one side tends to multi-home. ${ }^{103}$

\footnotetext{
${ }^{100}$ See United Kingdom's Merger Assessment Guidelines (2010) 57-58; OECD, "The Role of Efficiency Claims", 54-55; Federal Trade Commission, "The 'Sharing' Economy", 27-28.

${ }^{101}$ See E. Glen Weyl and Alexander White, "Let the Right 'One' Win: Policy Lessons from the New Economics of Platforms", Competition Policy International 10, no. 2 (2014): 28-51.

${ }^{102}$ OECD, "Policy Roundtables: Two-Sided Markets", 14-15.

${ }^{103}$ As the Commission implicitly recognised, the existence of the platforms (i.e., GDSs) "is justified by the added value it creates. A GDS coordinates the demand of TAs, thereby generating a positive
} 
Admittedly, the impact on dynamic efficiency is uncertain, and the presence of network effects makes the market dynamics very difficult to foresee. In fact, economists have only recently begun to develop the appropriate tools to assess network effects, which calls therefore for careful and light-handed public interventions in these very specific markets and consequently for an even more cautious approach in the assessment of a notified operation. ${ }^{104}$

\section{Conclusion}

To determine the impact of a merger on a two-sided market it is necessary to take into account the existence of network effects. The Commission considers that network effects constitute entry barriers when some requirements are met, but tends to ignore the interdependence between the different groups of users of the platform.

In this sense, the precise relevant product market definition is considered less important than making sure that direct and indirect network effects are adequately taken into account. However, the Commission defines as many markets as the products being offered to each group of users, even if they are offered free of charge, and subsequently assesses the competitive position of the platform in each of them. This could lead to erroneous results, since it conceals the linkage between its different groups of customers, which affects the ability of the platform to profitably increase prices. In particular, the link between the users of distinct sides affects the price elasticity of demand and, consequently, the profitability of a price increase on either side of the platform. Since the platform may influence the production level not only changing the price level, but also its structure, when the extra charge applied to one group of users of the platform is used to promote the demand of the users of the other group, in such a way that total output increases, that price increase on one side of the platform should not be considered as a sign of market power.

It remains to be seen what weight the Commission would give to efficiency if a proposed merger could drastically affect the structure of the

network externality which is internalised by the TSPs. Since they allow access to a broad network of TA outlets (and indirectly to a large number of end-consumers), GDS providers are effective distribution channels for TSPs ('network effect'). In particular, a centralised search for fares in one GDS is more effective and less time-consuming for TAs than multi-channel searches from numerous TSP-specific sources". See Travelport/Worldspan, 12.

${ }^{104}$ See Bruno Jullien and Wilfried Sand-Zantman, "Network Effects", 23; Justus Haucap and Ulrich Heimeshoff, "Google, Facebook, Amazon, eBay: Is the Internet Driving Competition or Market Monopolization?”, International Economics and Economic Policy 11 (2014): 49-61. 
market. Regulation 139/2004 explicitly clarified that the Commission should no longer limit its analysis to the structural outcome of the notified merger. On the contrary, the foreseeable effects of the merger on consumer welfare are to be considered. In this sense, the reinforcement of network effects that arise from a merger might enhance the ability and incentive of the merged entity to act pro-competitively for the benefit of consumers, even when it becomes a monopoly. Therefore, the encouragement and regulation of dominant efficient platforms have been considered an appropriate public policy. Yet, a more cautious approach is proposed for public intervention in general and merger control in particular.

\section{Bibliography}

Albaek, Svend. "Consumer Welfare in EU Competition Policy", in Aims and Values in Competition Law, edited by Caroline Heide-Jørgensen, Christian Bergqvist, Ulla Neergaard and Sune Troels Poulsen, 67-88. DJØF Publishing, 2013.

Auer, Dirk, and Nicolas Petit. "Two-Sided Markets and the Challenge of Turning Economic Theory into Antitrust Policy", The Antitrust Bulletin 60 (2015): 426-461. Autorité de la Concurrence and Bundeskartellamt. Competition Law and Data (2016). Broos, Sebastien, and Jorge Marcos Ramos. "Google, Google Shopping and Amazon: The Importance of Competing Business Models and Two-Sided Intermediaries in Defining Relevant Markets”, accessed July 2, 2017, https://papers.ssrn.com/sol3/ papers.cfm?abstract_id=2696045.

Bundeskartellamt. "Working Paper - Market Power of Platforms and Networks" (2016).

Caillaud, Bernard, and Bruno Jullien. "Chicken and Egg: Competition among Intermediation Service Providers”, RAND Journal of Economics 34 (2003): 309-328.

Commission communication of 25 May 2016 on "Online Platforms and the Digital Single Market - Opportunities and Challenges for Europe" (COM(2016)288).

Commission Notice on the definition of relevant market for the purposes of Community competition law, [1997] OJ C 372/5.

Commission staff working document accompanying the Commission communication "Online Platforms and the Digital Single Market - Opportunities and Challenges for Europe" (SWD(2016)0172).

Costa-Cabral, Francisco, and Orla Lynskey. "The Internal and External Constraints of Data Protection on Competition Law in the EU", LSE Law, Society and Economy Working Papers 25/2015, SSRN Electronic Journal, accessed 3 August 2017: http://eprints.lse.ac.uk/64887/1/Lynskey_Internal\%20and\%20External\%20 Constraints\%20of\%20Data\%20Protection\%20_Author_2015.pdf. 
Doganoglu, Toker, and Julian Wright. "Multihoming and Compatibility", International Journal of Industrial Organization 24 (2006), 45-67.

Evans, David S. "Multisided Platforms, Dynamic Competition, and the Assessment of Market Power for Internet-Based Firms", University of Chicago Coase-Sandor Institute for Law \& Economics Research Paper No. 753: 23-31, accessed July 2, 2017: https://papers.ssrn.com/sol3/papers.cfm?abstract_id=2746095.

Evans, David S. "The Antitrust Economics of Multi-Sided Platform Markets”, Yale Journal on Regulation 20 (2003): 325-381.

Evans, David S. "The Antitrust Economics of Two-Sided Markets”, accessed July 2, 2017: https://papers.ssrn.com/sol3/papers.cfm?abstract_id=332022.

Evans, David S., and Richard Schmalensee. "Market Definition and Merger Analysis for Multi-Sided Platforms", Competition Policy International (2012), accessed July 2, 2017: https://www.competitionpolicyinternational.com/assets/Uploads/MSP11-13-3.pdf.

Evans, David S., and Richard Schmalensee. "The Industrial Organization of Markets with Two-Sided Platforms", Competition Policy International 3, no. 1 (2007): 150-179.

Evans, David S., and Vanessa Yanhua Zhang. "Qihoo 360 v Tencent: First Antitrust Decision by The Supreme Court", CPI blog, accessed July 2, 2017: https://www.competitionpolicyinternational.com/assets/Uploads/AsiaOctober214.pdf.

Federal Trade Commission. “The 'Sharing' Economy. Issues Facing Platforms, Participants \& Regulators" (2016).

Ferro, Miguel Sousa. “'Ceci n'est pas un Marché’: Gratuity and Competition Law”, accessed July 2, 2017, https://papers.ssrn.com/sol3/papers.cfm?abstract_id=2493236.

Filistrucchi, Lapo. "A SSNIP Test for Two-Sided Markets: The Case of Media”, NET Institute Working Paper 08-34, October 2008.

Filistrucchi, Lapo, Damien Geradin, Eric van Damme, and Pauline Affeldt. "Market Definition in Two-Sided Markets: Theory and Practice", Journal of Competition Law and Economics 10 (2014): 293-339.

Gawer, Anabelle. "Competition Policy and Regulatory Reforms for Big Data: Propositions to Harness the Power of Big Data while Curbing Platforms' Abuse of Dominance", in OECD, Big Data: Bringing Competition Policy to the Digital Era, $\mathrm{DAF} / \mathrm{COMP} / \mathrm{WD}(2016) 74$.

Graef, Inge. EU Competition Law, Data Protection and Online Platforms: Data as Essential Facility, Kluwer Law International, 2016.

Graef, Inge. "How can Software Interoperability be Achieved under European Competition Law and Related Regimes?", Journal of European Competition Law \& Practice 5 (2014): 6-19.

Graef, Inge. "Market Definition and Market Power in Data: The Case of Online Platforms", World Competition Law and Economics Review 38 (2015): 473-506. 
Haucap, Justus, and Ulrich Heimeshoff. "Google, Facebook, Amazon, eBay: Is the Internet Driving Competition or Market Monopolization?", International Economics and Economic Policy 11 (2014): 49-61.

Herrera Anchústegui, Ignacio. Buyer Power in EU Competition Law. Bergen: University of Bergen, 2017.

House of Lords. Select Committee on European, "Online Platforms and the Digital Single Market", 2016.

Jullien, Bruno. "Two-Sided Markets and Electronic Intermediaries", CESifo Economic Studies 51, no. 2-3 (2005): 233-260, also accessible at https://ideas.repec.org/p/ces/ ceswps/_1345.html.

Jullien, Bruno, and Wilfried Sand-Zantman. "Network Effects”, Institut D'Economie Industrielle, June 2016.

Kahn, Lina M. “The Amazon Paradox”, Yale Law Journal 126 (2017): 710-805.

Kaplow, Louis. "Why (Ever) Define Markets?", Harvard Law Review 124 (2010): 437-517.

Katz, Michael, and Carl Shapiro. "Network Externalities, Competition, and Compatibility", American Economic Review 75 (1985): 424-440.

Katz, Michael, and Carl Shapiro. "Systems of Competition and Network Effects", The Journal of Economic Perspectives 8 (1994): 93-115.

Lamadrid, Alfonso. "Déjà Vu? Microsoft Announces Skype’s Integration in Windows", Chillin' Competition, 2 September 2013.

Lerner, Andres V. “The Role of 'Big Data' in Online Platform Competition”, SSRN Electronic Journal, (2014), accessed 3 August 2017: http://papers.ssrn.com/sol3/ papers.cfm?abstract_id=2482780.

Lougher, Guy, and Sammy Kalmanowicz. "EU Competition Law in the Sharing Economy", Journal of European Competition Law and Practice 7 (2016): 87-102.

Monopolkommission. "Competition Policy: The Challenge of Digital Markets", Special Report No. 68 (2015).

Newman, M. E. J. “The Structure and Function of Complex Networks", 1-4, accessed July 2, 2017: http://www-personal.umich.edu/ mejn/courses/2004/cscs535/review.pdf.

OECD. "Policy Roundtables: The Role of Efficiency Claims in Antitrust Proceedings", 2012.

OECD. "Policy Roundtables: Two-Sided Markets", 2009.

Petróczi, Andrea, Tamás Nepusz, and Fülöp Bazsó. “Measuring Tie-Strength in Virtual Social Networks", Connections 27 (2007): 39-52.

Robles Martín-Laborda, Antonio. "Sexo, Mentiras y Efectos de Red. Sobre la Compra de WhatsApp por Parte de Facebook", Competencia y Regulación, accessed July 2, 2017, http://derechocompetencia.blogspot.com.es/2017/01/sexo-mentiras-y-efectos-de-red.html. 
Rochet, Jean-Charles, and Jean Tirole. "An Economic Analysis of the Determination of Interchange Fees in Payment Card Systems", Review of Network Economics no. 2 (2003): 69-79.

Rochet, Jean-Charles, and Jean Tirole. "Platform Competition in Two-Sided Markets", Journal of the European Economic Association 1 (2003): 990-1029.

Schrepel, Thibault. "Predatory Innovation: The Definite Need for Legal Recognition", accessed July 21, 2017: https://ssrn.com/abstract=2997586.

Stucke, Maurice E., and Ariel Ezrachi. "When Competition Fails to Optimize Quality: A Look at Search Engines", Yale Journal of Law and Technology 18 (2016): 70-110.

Thépot, Florence. "Market Power in Online Search and Social Networking: A Matter of Two-Sided Markets", World Competition 36 (2013): 95-221.

Thomas, Christopher. "Intel and McAfee - Antitrust is 'Getting it Right' in High Tech", CPI Antitrust Journal 2 (2011).

United Kingdom's Merger Assessment Guidelines (2010).

Van Arsdale, Suzanne, and Cody Venzke. "Predatory Innovation in Software Markets", Harvard Journal of Law \& Technology 29 (2015): 243-290.

Van Steen Version, Maarten. An Introduction to Graph Theory and Complex Networks (2010): 1.3-1.13, accessed July 2, 2017: https://pdfs.semanticscholar.org/9dba/ e30f8253791138e6c1031c5b7e4c7b321185.pdf.

Weyl, E. Glenn, and Alexander White. "Let the Right 'One' Win: Policy Lessons from the New Economics of Platforms", Competition Policy International 10, no. 2 (2014): 28-51.

Williamson, Oliver E. "Economies as an Antitrust Defense: The Welfare Tradeoffs", The American Economic Review 1 (1968): 18-36.

Wright, Julian. "One-Sided Logic in Two-Sided Markets", Revue of Network Economics 3 (2004): 44-64.

Zimmer, Daniel. "Digital Markets: New Rules for Competition Law", Journal of European Competition Law and Practice 6 (2015): 627-628. 